University of Nebraska - Lincoln

DigitalCommons@University of Nebraska - Lincoln

Faculty Publications: Department of

Entomology

Entomology, Department of

6-1-2021

\title{
Presence-Absence Sampling Plans for Stink Bugs (Hemiptera: Pentatomidae) in the Midwest Region of the United States
}

\author{
Rafael Carlesso Aita \\ University of Minnesota Twin Cities \\ Daniela T. Pezzini \\ NC State University \\ Eric C. Burkness \\ University of Minnesota Twin Cities \\ Christina D. Difonzo \\ Michigan State University \\ Deborah L. Finke \\ University of Missouri
}

See next page for additional authors

Follow this and additional works at: https://digitalcommons.unl.edu/entomologyfacpub

Part of the Entomology Commons

Carlesso Aita, Rafael; Pezzini, Daniela T.; Burkness, Eric C.; Difonzo, Christina D.; Finke, Deborah L.; Hunt, Thomas E.; Knodel, Janet J.; Krupke, Christian H.; Marchi-Werle, Lia; McCornack, Brian; Michel, Andrew P.; Philips, Christopher R.; Seiter, Nicholas J.; Varenhorst, Adam J.; Wright, Robert J.; Hutchison, William D.; and Koch, Robert L., "Presence-Absence Sampling Plans for Stink Bugs (Hemiptera: Pentatomidae) in the Midwest Region of the United States" (2021). Faculty Publications: Department of Entomology. 961. https://digitalcommons.unl.edu/entomologyfacpub/961

This Article is brought to you for free and open access by the Entomology, Department of at DigitalCommons@University of Nebraska - Lincoln. It has been accepted for inclusion in Faculty Publications: Department of Entomology by an authorized administrator of DigitalCommons@University of Nebraska - Lincoln. 


\section{Authors}

Rafael Carlesso Aita, Daniela T. Pezzini, Eric C. Burkness, Christina D. Difonzo, Deborah L. Finke, Thomas E. Hunt, Janet J. Knodel, Christian H. Krupke, Lia Marchi-Werle, Brian McCornack, Andrew P. Michel, Christopher R. Philips, Nicholas J. Seiter, Adam J. Varenhorst, Robert J. Wright, William D. Hutchison, and Robert L. Koch 


\title{
Presence-Absence Sampling Plans for Stink Bugs (Hemiptera: Pentatomidae) in the Midwest Region of the United States
}

\author{
Rafael Carlesso Aita, ${ }^{1,}$ Daniela T. Pezzini, ${ }^{2}$ \\ Eric C. Burkness, ${ }^{1}$ Christina D. DiFonzo, ${ }^{3}$ \\ Deborah L. Finke, ${ }^{4}$ Thomas E. Hunt, ${ }^{5}$ \\ Janet J. Knodel, ${ }^{6}$ Christian H. Krupke, ${ }^{7}$ \\ Lia Marchi-Werle, ${ }^{8}$ Brian McCornack, ${ }^{9}$ \\ Andrew P. Michel, ${ }^{10}$ Christopher R. Philips, ${ }^{11}$ \\ Nicholas J. Seiter, ${ }^{12}$ Adam J. Varenhorst, ${ }^{13}$ \\ Robert J. Wright, ${ }^{14}$ William D. Hutchison, ${ }^{1}$ \\ and Robert L. Koch ${ }^{1}$
}

1 Department of Entomology, University of Minnesota, 1980 Folwell Avenue, Saint Paul, MN 55108

2 Department of Entomology and Plant Pathology, North Carolina State University, 207 Research Station Road, Plymouth, NC 27962

3 Department of Entomology, Michigan State University, 243 Natural Science Building, East Lansing, MI 48824-1311

4 Division of Plant Sciences, University of Missouri-Columbia, Columbia, MO 65211

5 Haskell Agricultural Laboratory, Department of Entomology, University of Nebraska, 57905866 Road, Concord, NE 68728

6 Department of Plant Pathology, Extension Entomology, North Dakota State University, Fargo, ND 58108-6050

7 Department of Entomology, Purdue University, 901 West State Street, West Lafayette, IN 47907

Published in Journal of Economic Entomology, 114:3 (2021), pp 1362-1372.

doi: 10.1093/jee/toab076

Copyright (C) 2021 by the authors. Published by Oxford University Press on behalf of Entomological Society of America. Used by permission.

Submitted 25 January 2021; accepted 29 March 2021; published 22 April 2021. 
8 Department of Agronomy, University of Wisconsin, 1575 Linden Drive, Madison, WI 53706

9 Department of Entomology, Kansas State University, 123 W. Waters Hall, 1603

Old Claflin Place, Manhattan, KS 66506

10 Department of Entomology, Ohio Agricultural Research and Development Center, The Ohio State University, 210 Thorne, 1680 Madison Avenue, Wooster, $\mathrm{OH} 44691$

11 Department of Entomology, Virginia Tech, 170 Drillfield Drive, 220 Price Hall Blacksburg, VA 24061-0319

12 Department of Crop Sciences, University of Illinois, 380 NSRC, 1101 W. Peabody Drive, Urbana, IL 61801, USA,

13 Department of Agronomy, Horticulture and Plant Science, South Dakota State University, SAG 308, Brookings, SD 57007, USA,

14 Department of Entomology, University of Nebraska-Lincoln, 213 Entomology Hall, Lincoln, NE 68583-0816, USA

Corresponding author — R. L. Koch, tel: +1 612-624-6771, email: koch0125@umn.edu

\title{
ORCID
}

Rafael Carlesso Aita https://orcid.org/0000-0002-9347-0196

Andrew P. Michel https://orcid.org/0000-0002-2953-9187

Nicholas J. Seiter https://orcid.org/0000-0003-0557-265X

Robert L. Koch https://orcid.org/0000-0002-4853-3573

\begin{abstract}
Stink bugs represent an increasing risk to soybean production in the Midwest region of the United States. The current sampling protocol for stink bugs in this region is tailored for population density estimation and thus is more relevant to research purposes. A practical decision-making framework with more efficient sampling effort for management of herbivorous stink bugs is needed. Therefore, a binomial sequential sampling plan was developed for herbivorous stink bugs in the Midwest region. A total of 146 soybean fields were sampled across 11 states using sweep nets in 2016, 2017, and 2018. The binomial sequential sampling plans were developed using combinations of five tally thresholds at two proportion infested action thresholds to identify those that provided the best sampling outcomes. Final assessment of the operating characteristic curves for each plan indicated that a tally threshold of 3 stink bugs per 25 sweeps, and proportion infested action thresholds of 0.75 and 0.95 corresponding to the action thresholds of 5 and 10 stink bugs per 25 sweeps, provided the optimal balance between highest probability of correct decisions ( $\geq 99 \%$ ) and lowest probability of incorrect decisions ( $\leq 1 \%)$. In addition, the average sample size for both plans (18 and 12 sets of 25 sweeps, respectively) was lower than that for the other proposed plans. The binomial sequential sampling plan can reduce the number of sample units required to achieve a management decision, which is important because it can potentially reduce risk/cost of management for stink bugs in soybean in this region.
\end{abstract}

Keywords: soybean, stink bug, binomial sampling, insect sampling, resampling software 
Soybean, Glycine max (L.) Merr. (Fabales: Fabacea), is one of the most $S$ valuable crops globally, representing one of the largest sources of vegetable oil and animal protein feed (Pagano and Miransari 2016). The United States leads the world in soybean production and is the second in exports, comprising about $90 \%$ of the country's total oilseed production (U.S. Department of Agriculture-Economic Research Service [USDA-ERS] 2020). The Midwest region of the United States accounts for $82 \%$ of the soybean acreage in the United States (U.S. Department of Agriculture-National Agricultural Statistics Service [USDA-NASS] 2019). Worldwide, stink bugs (Hemiptera: Pentatomidae) are significant pests of this crop (Kogan 1976). In the Midwest region, stink bugs were historically insignificant pests (McPherson and McPherson 2000). However, in recent years, the threat posed to soybean production by stink bugs in the region is increasing (Koch et al. 2017).

The increasing risk posed by stink bugs can be attributed to a few factors (Koch et al. 2017, Pezzini et al. 2019b). First, native stink bug species abundance is increasing in agricultural crops in the Midwest region (Koch et al. 2017), perhaps due to warmer winter temperatures or the increased adoption of reduced-tillage systems (Panizzi 2015, Kistner 2017, McPherson 2018). Across the region, the predominant species of native stink bugs in soybean are the green stink bug, Chinavia hilaris (Say) (Hemiptera: Pentatomidae), brown stink bugs, Euschistus servus servus (Say) (Hemiptera: Pentatomidae) and Euschistus servus euschistoides (Vollenhoven) (Hemiptera: Pentatomidae), onespotted stink bug, Euschistus variolarius (Palisot de Beauvois) (Hemiptera: Pentatomidae), and red-shouldered stink bug, Thyanta custator accerra McAtee (Hemiptera: Pentatomidae) (Koch and Pahs 2014, Koch and Rich 2015, Pezzini et al. 2019b). Second, invasive stink bugs are spreading into this region (Tindall and Fothergill 2011, Tindall et al. 2012, Koch 2014, Koch et al. 2018). An example is the brown marmorated stink bug, Halyomorpha halys (Stal) (Hemiptera: Pentatomidae), first detected in North America in 1996 (Hoebeke and Carter 2003). Since then, $H$. halys has spread to 46 U.S. states and 4 Canadian provinces, including 11 states in the Midwest region (Northeastern IPM Center [NIPMC] 2020). Growers in the Mid-Atlantic region reported up to $50 \%$ yield reduction in soybean due to injuries caused by H. halys (Leskey et al. 2012). 
In soybean, stink bugs prefer to feed on the reproductive plant parts such as the seeds and pods, resulting in irreversible damage that leads to impacts on seed quality, yield, and germination rates (reviewed by McPherson and McPherson [2000] and Koch et al. [2017]). This potential damage to soybean necessitates the development of practical, cost-effective sampling plans for making integrated pest management (IPM)-based control decisions (Binns et al. 2000). The time required to sample pest insects is a key bottleneck to effective monitoring in the field. Sampling for stink bugs in soybean can be done with a sweep net or drop cloth (Koch et al. 2017). Both methods are efficient, but sweeping is found to be more convenient and costeffective for several stink bug species (Todd and Herzog 1980, Sane et al. 1999, Koch et al. 2017).

Sampling plans can have different purposes, such as detection, estimation, and decision making (Moon and Wilson 2008, Pezzini et al. 2019a). Sequential sampling plans can be more efficient than fixed sample size sampling plans, allowing for more flexibility in sample size while reducing sampling effort, and retaining high levels of precision (Binns et al. 2000). Density estimation, or enumerative sequential sampling, is used to estimate pest density in the field based on a pre-established precision level, and even though it can be utilized for decision making (Hodgson et al. 2004), this approach is often used for research purposes due to high sample size requirements (Hutchison 1994, Galvan et al. 2007, Pezzini et al. 2019a). For decision making in IPM programs, binomial sequential sampling plans, which incorporate a "tally threshold," are an attractive option. The tally threshold (i.e., number of insects necessary to consider a sample unit "infested") requires only information on the presence or absence of the targeted pest above a specified level to make a decision, resulting in a more efficient, time-saving option (Jones 1994, Burkness and Hutchison 2009, Paula-Moraes et al. 2011, Araujo et al. 2020, Lindenmayer et al. 2020). In addition, binomial sequential sampling plans often facilitate a rapid decision when pest densities are much lower or higher than the economic threshold, potentially reducing sample size by up to $50 \%$ compared to fixed sample size plans (Jones 1994, Burkness and Hutchison 1997, 2009; Hodgson et al. 2004).

There have been no binomial sequential sampling plans developed for stink bugs in the Midwest region. Given the practicality and 
efficiency of binomial sequential sampling plans, and the need to aid growers with decision making for improved IPM of these pests, the objective of this study was to develop and validate the performance of several binomial sequential sampling plans. The sampling plans we evaluated included the composite action thresholds (all herbivorous stink bug species combined) currently used in the Midwest region i.e., 5 stink bugs per 25 sweeps for soybean grown for seed and 10 stink bugs per 25 sweeps for soybean grown for grain (Kogan 1976, Koch et al. 2017). We also proposed several different tally thresholds that can be used in the field for characterizing a sample unit as infested. Finally, the sampling plan combinations were developed and validated using resampling software (Naranjo and Hutchison 1997), which included estimates of the probability of making correct decisions (i.e., treat or not-treat). Results of this study provide a decision-making framework for IPM implementation to be used for herbivorous stink bugs in soybean, which is an advancement from the work by Pezzini et al. (2019a) to develop a sequential sampling plan for density estimation.

\section{Materials and Methods}

\section{Insect Data}

Stink bug nymphs and adults were sampled from 146 soybean fields across 11 states in the Midwest region during 2016, 2017, and 2018 (Table 1). For the data collected in 2016 and 2017, sampling protocols (i.e., field sites and data collection) are described in Pezzini et al. (2019a), where an enumerative sequential sampling plan was developed. Briefly, sampling occurred in eight states (63 fields) in 2016 and nine states (62 fields) in 2017 (Table 1). In each state, one to four sites were selected with 13-368 km between sites, and at each site, one to four fields were sampled. In 2018, 21 fields were sampled in eight states (Table 1). In each state, two separate fields were sampled, except for Michigan which had seven fields. Within each state, fields were $0.92-116 \mathrm{~km}$ apart. In general, fields were sampled every week from R1 to R8 soybean growth stages (i.e., beginning bloom to full maturity, respectively) (Fehr and Caviness 1977). 
Table 1. Number of fields sampled for herbivorous stink bugs in soybean across the participating states in the Midwest region of the United States for 2016, 2017, and 2018

\begin{tabular}{lrrr} 
State & 2016 & 2017 & 2018 \\
\hline Illinois & 0 & 0 & 2 \\
Indiana & 8 & 8 & 2 \\
Kansas & 8 & 7 & 0 \\
Michigan & 0 & 8 & 7 \\
Minnesota & 12 & 8 & 2 \\
Missouri & 8 & 4 & 0 \\
Nebraska & 7 & 8 & 2 \\
North Dakota & 8 & 8 & 2 \\
Ohio & 8 & 3 & 2 \\
South Dakota & 4 & 0 & 0 \\
Wisconsin & 0 & 62 & 2 \\
Total & 63 & & 21 \\
\hline
\end{tabular}

Adapted from Pezzini et al. (2019a).

Sampling was done using sweep nets (39-cm net diameter). A sample unit was a set of 25 sweeps (i.e., sample unit size of 25 sweeps). Sweeps were performed using vertical pendulum-style swings of the net through two adjacent rows of soybean as the sampler walked between the rows, resulting in the sweep net passing only once through the same plants in the field; one full pendulum-style swing counted as one sweep (Kogan and Pitre 1980). In 2016 and 2017, 12-50 sample units were collected from randomly selected locations at the field edge (i.e., $<10 \mathrm{~m}$ into the field) and in the field interior (i.e., $>10 \mathrm{~m}$ into the field) (Pezzini et al. 2019a,b). In 2018, 15 sample units were collected from the interior of each field (i.e., $>10 \mathrm{~m}$ into the field) on a given date. For all years, at least $10 \mathrm{~m}$ separated sample units in each field. The contents of each set of sweeps was transferred into plastic zipper-locking bags $(20.3 \times 25.4 \mathrm{~cm})$ and brought to the laboratory for later processing. The contents of the bags were sorted to retain only stink bug nymphs and adults and sent to the University of Minnesota for identification. Nymphs and adults were identified to genus, species, and subspecies using DeCoursey and Esselbaugh (1962), Evans (1985), McPherson and McPherson (2000), Rider (2012), and Paiero et al. (2013). For the purpose of this research, only the herbivorous stink bugs were quantified. 


\section{Binomial Sequential Sampling Plans}

A total of 885 data sets (i.e., each data set was a group of sample units collected on a given date from a given field) were collected over all years. However, data sets with a mean density of zero (i.e., without any stink bugs; 178 data sets) were excluded from the analysis. The binomial sequential sampling plans were developed and validated from 707 data sets using Resampling for Validation of Sampling Plans (RVSP) software v. 2.0 (Excel add-in) developed by Naranjo and Hutchison (1997). Steps to develop the binomial sequential sampling plans followed methodologies used by Burkness et al. (1999), Hodgson et al. (2004), Galvan et al. (2007), and Lindenmayer et al. (2020). Several parameters are needed to create the stop-lines for the Wald's sequential probability ratio test (Wald 1947); 1 ) tally threshold, 2) proportion infested action threshold (based on proportion of infested sample units), 3) upper and lower boundaries around the proportion infested action threshold, and 4) type I and II error rates (Jones 1994). The type I error $(\alpha)$ is defined as the probability of making a decision to treat when proportion of infested sample units is below the proportion infested action threshold and type II error $(\beta)$ is defined as the probability of making a decision to not treat when proportion of infested sample units is above the proportion infested action threshold. The lower and upper boundaries were set at 0.03 (above or below the proportion infested action threshold), and type I and II errors were set at 0.10 (Binns 1994, Burkness and Hutchison 2009, PaulaMoraes et al. 2011, Araujo et al. 2020). For all the tally threshold and proportion infested action threshold combinations, the parameters were kept constant. For each proportion infested action threshold and tally threshold combination, the stop-lines were calculated using Wald's plan (Wald 1947). The 707 data sets were iteratively resampled using 500 resampling bouts (with replacement) until a decision to treat or not to treat was made. The software simulations provided the average proportion of infested sample units, the operating characteristic (OC) function, and the average sample number (ASN). The OC corresponds to the probability of not taking action against an insect population relative to the observed proportion of infested sample units (Onsager 1976), and ASN represents the average sample size required for making a decision. 
We evaluated multiple combinations of tally threshold and action threshold to identify those that provided the best sampling outcomes. Two mean densities were used to develop the proportion infested action threshold (i.e., action thresholds in terms of proportion of infested sample units). These densities, which are the recommended action thresholds for stink bugs in soybean in the Midwest region, are 5 stink bugs per 25 sweeps for soybean grown for seed and 10 stink bugs per 25 sweeps for soybean grown for grain (Kogan 1976, Koch et al. 2017). In addition, we independently evaluated five tally thresholds (i.e., 1, 2, 3, 4, and 5 stink bugs per 25 sweeps), meaning that for a sample unit (i.e., set of 25 sweeps) to be considered infested, at least one, two, three, four, or five stink bugs must be present, respectively. For each tally threshold, the relationship between the mean density and proportion of infested sample units based on that tally threshold was used to calculate proportion infested action threshold for the densities of 5 and 10 stink bugs per 25 sweeps.

For decision-making purposes, the efficiency and precision of a sampling plan are what best characterize its appropriateness (Galvan et al. 2007). The OC function determines precision and ASN function determines efficiency (Binns and Nyrop 1992). Therefore, to validate the sampling plans' precision, $O C$ functions were plotted against the observed proportion of infested sample units for each tally threshold and proportion infested action threshold combination. In addition, the efficiency of the sampling plans was validated by plotting the ASN functions against the observed proportion of infested sample units for each tally threshold and proportion infested action threshold combination. Models for the relationships between mean density and proportion of infested sample units, OC, and ASN were fitted using the software, TableCurve 2D (Systat Software, Inc., San Jose, CA). The predicted lines for the relationship between mean density and proportion of infested sample units and OC functions were fitted using a logistic dose-response function:

$$
\left[y=a /\left(1+(x / b)^{c}\right)\right]
$$

where $a, b$, and $c$ are parameters to be estimated, and $x$ is mean density of stink bugs. These parameter estimates are presented in Supplementary Tables S1 and S2. 
The ASN functions were fitted using a Pearson VII function:

$$
\left[y=a+b /\left(1+4 \times((x-c) / d)^{2}\left(2^{(1 / e)-1}\right)\right)^{e}\right],
$$

where, $a, b, c, d$, and $e$ are parameters to be estimated, and $x$ is the mean density of stink bugs. These parameter estimates are presented in Supplementary Table S3.

To aid in the validation process, a decision probability matrix was used to evaluate the accuracy of the sampling plans, similar to the approach used by Calvin et al. (1986), Burkness et al. (1999), Hodgson et al. (2004), Galvan et al. (2007), Burkness and Hutchison (2009), and Paula-Moraes et al. (2011). The results obtained from the OC curves, jointly with the observed and average proportion infested, were used in the decision probability matrix to calculate the probability of making a correct decision (i.e., treating when population exceeds the threshold or not treating when the population is below the threshold), by comparing the observed proportion infested (i.e., average proportion of infested sample units calculated from actual field data) to the average proportion infested (i.e., average proportion of infested sample units generated from the 500 resampling bouts in the software simulation) at each action threshold. The decision probability matrix contains four cells, including correct decisions to treat (cell $A$ ) and not treat (cell $D$ ), and incorrect decisions to not treat (cell $B$ ) and to treat (cell $C$ ). A decision to correctly treat $(A)$ or not treat $(D)$ is made when the observed and average proportion infested both exceeded or did not exceed, respectively, the proportion infested action threshold. A decision to incorrectly not treat $(B)$ is made when the observed proportion infested exceeded the proportion infested action threshold and the average proportion infested did not exceed the proportion infested action threshold. Conversely, a decision to incorrectly treat $(C)$ is made when the observed proportion infested did not exceed the proportion infested action threshold and the average proportion infested exceeded the proportion infested action threshold. In the probability matrix, the decision for each data set evaluated is determined by the density and must be correct or incorrect (i.e., $A+B$ or $C+D$ must equal 1 ) (Burkness et al. 1999, Hodgson et al. 2004, Galvan et al. 2007). The probability of making correct decisions to treat or not to treat was summed across all data sets at each tally threshold and proportion 
infested action threshold combination with

$$
1=\sum p_{i}\left(A_{i}+D_{i}\right)+\sum p_{i}\left(B_{i}+C_{i}\right)
$$

where $p_{i}$ is the proportion of $n$ data sets represented by data set $i$, and $A, D, B$, and $C$ were described above.

The correct and incorrect decisions were totaled for each combination of tally threshold and proportion infested action threshold. The best sampling plan was then selected based on the greatest probability of making correct decisions while minimizing the probability of incorrect decisions, and on the balance among OC, ASN, and actual $\alpha$ and $\beta$ error values. Based on this, graphs with decision stop-lines for the best combinations of tally threshold and proportion infested action threshold were developed (Wald 1947). The proportion of infested sample units can be calculated and compared with the decision stop-lines. From this, a management decision can be achieved if the proportion is in the "treat" or "do not treat" area of the graphs. If the value is in the "continue sampling" area, additional sample units will be required before a management decision is achieved. The minimum number of sample units to reach a decision to treat or not treat is determined when the lower stop-line intercepts the $x$-axis.

\section{Results}

Across all states and years, 9,433 specimens from 17 species of adults and six genera of nymphs of herbivorous stink bugs were collected from soybean fields (Table 2). The mean number of herbivorous stink bugs per 25 sweeps ranged from 0.02 to 15.58 for the 707 data sets with at least one stink bug (i.e., each data set was a group of sample units collected on a given data from a given field). Proportion infested action thresholds were calculated for each tally threshold based on the relationship between mean density and proportion of infested sample units for the densities of 5 and 10 stink bugs per 25 sweeps (Fig. 1). For the mean density of five stink bugs per 25 sweeps and tally thresholds of $1,2,3,4$, and 5 stink bugs per 25 sweeps, the calculated proportion infested action threshold values were $0.95,0.86$, $0.75,0.62$, and 0.49 , respectively. For the mean density of 10 stink 
Table 2. Relative abundance of stink bug nymphs and adults collected from soybean from 2016 to 2018 in the Midwest region of the United States.

\begin{tabular}{lrr} 
Species & $\begin{array}{r}\text { Total number } \\
\text { of individuals }\end{array}$ & $\begin{array}{r}\text { Relative } \\
\text { abundance (\%) }\end{array}$ \\
\hline Adults & & \\
Banasa dimidiata & 1 & 0.03 \\
Chinavia hilaris & 916 & 31.10 \\
Coenus delius & 3 & 0.10 \\
Cosmopepla lintneriana & 9 & 0.31 \\
Euschistus servus servus & 105 & 3.57 \\
Euschistus servus euschistoides & 69 & 2.34 \\
Euschistus servus hybrid & 36 & 1.22 \\
Euschistus tristigmus luridus & 44 & 1.49 \\
Euschistus tristigmus tristigmus & 20 & 0.68 \\
Euschistus variolarius & 1,539 & 52.26 \\
Halyomorpha halys & 94 & 3.19 \\
Holcostethus limbolarius & 4 & 0.14 \\
Mormidea lugens & 1 & 0.03 \\
Oebalus pugnax & 8 & 0.27 \\
Thyanta calceata & 6 & 0.20 \\
Thyanta custator accerra & 89 & 3.02 \\
Trichopepla semivittata & 1 & 0.03 \\
Nymphs & & \\
Chinavia hilaris & 1,438 & 22.16 \\
Chlorochroa spp. & 2 & 0.03 \\
Euschistus spp. & 4,853 & 74.80 \\
Halyomorpha halys & 141 & 2.17 \\
Oebalus pugnax & 31 & 0.48 \\
Thyanta spp. & 23 & 0.35 \\
\hline
\end{tabular}

bugs per 25 sweeps and tally thresholds of 3, 4, and 5 stink bugs per 25 sweeps, the calculated proportion infested action threshold values were $0.95,0.94$, and 0.88 , respectively. Proportion infested action threshold values that correspond to the mean density of 10 stink bugs per 25 sweeps for the tally thresholds of 1 and 2 stink bugs per 25 sweeps were not included in the OC and ASN calculations because their associated upper boundaries (i.e., 0.03 above the proportion infested action threshold) would exceed 1.

The OC function curves for each proportion infested action threshold associated with the respective tally thresholds showed varying levels of precision among sampling plans. For a mean density threshold of 5 stink bugs per 25 sweeps, the OC for tally thresholds of 1,2 , 3,4 , and 5 stink bugs per 25 sweeps were $0.36,0.36,0.51,0.46$, and 

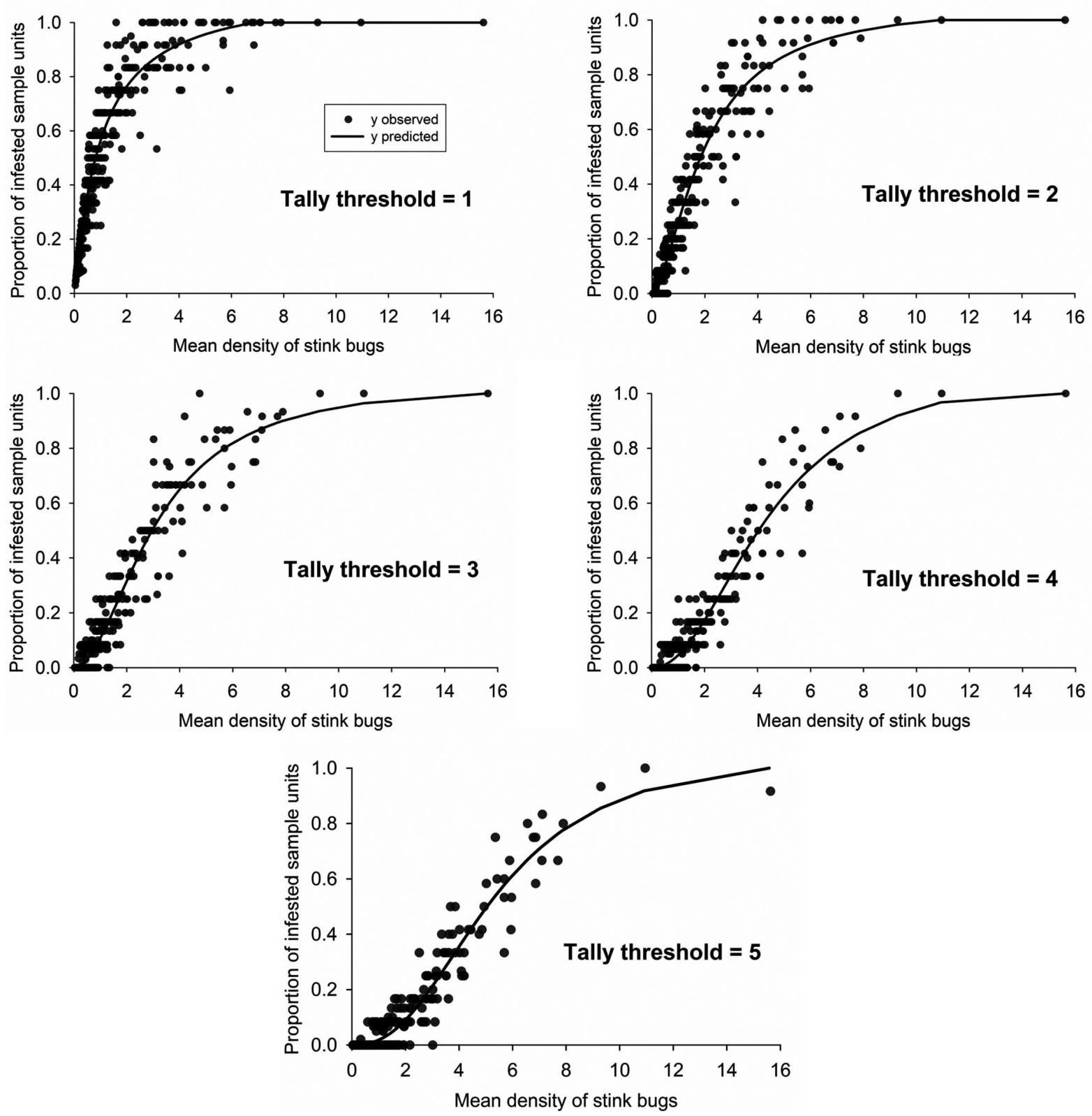

Fig. 1. Relationship between the proportion of infested sample units (i.e., sets of 25 sweeps) and mean density of herbivorous stink bugs (i.e., bugs per 25 sweeps) for tally thresholds of $\geq 1,2,3$, , or 5 stink bugs per sample unit.

0.42 respectively (Fig. $2 A, C, E, G$, and I). Ideally, when $\alpha=\beta$, the OC should be equal to 0.5 at the proportion infested action threshold (i.e., 50\% chance of treating or not treating) (Naranjo and Hutchison 1997, Binns et al. 2000). For all the sampling plans, except for tally threshold of 3 stink bugs per 25 sweeps, the OC values at the 

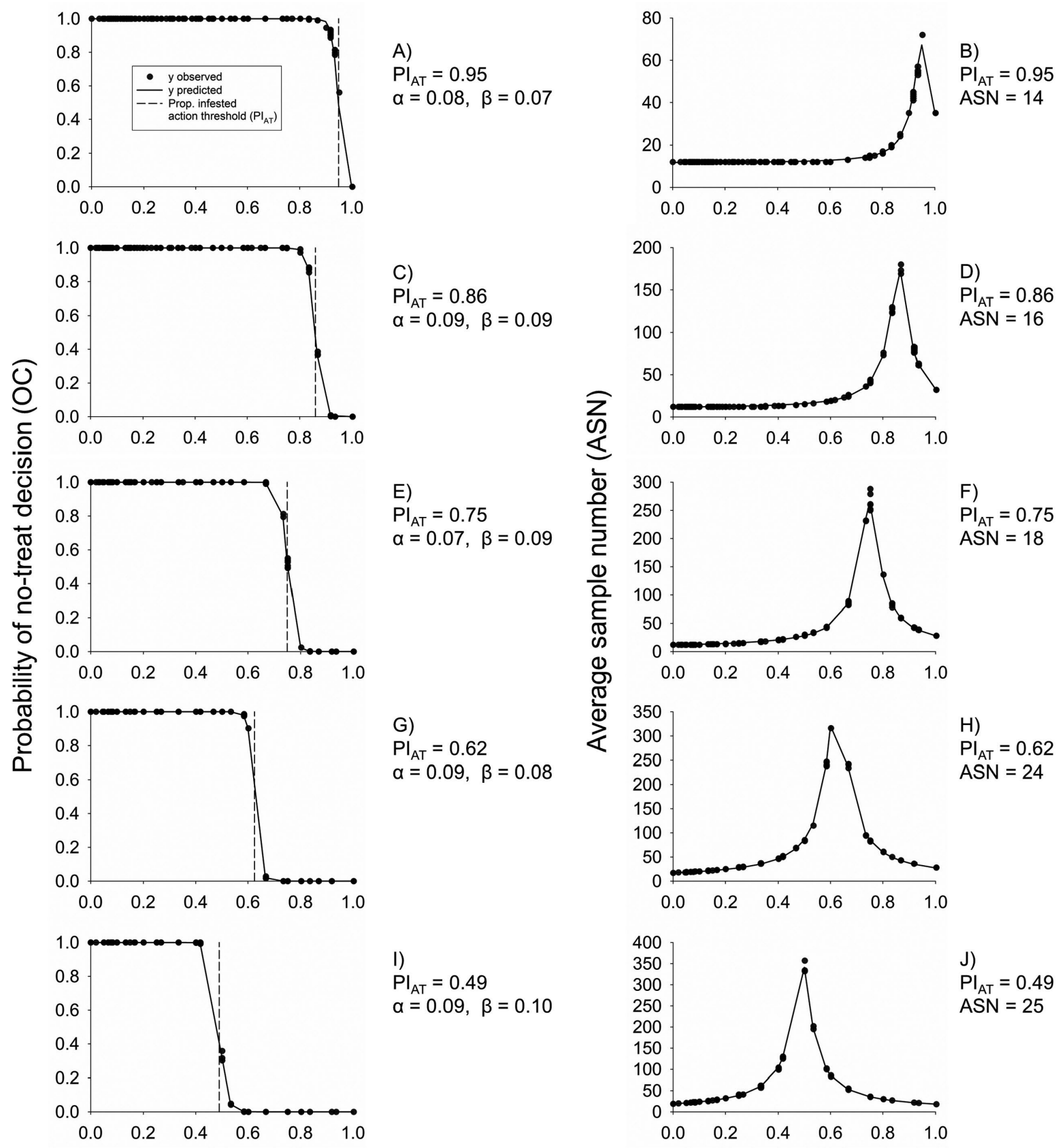

I)
$\mathrm{PI}_{\text {AT }}=0.49$
$\alpha=0.09, \quad \beta=0.10$

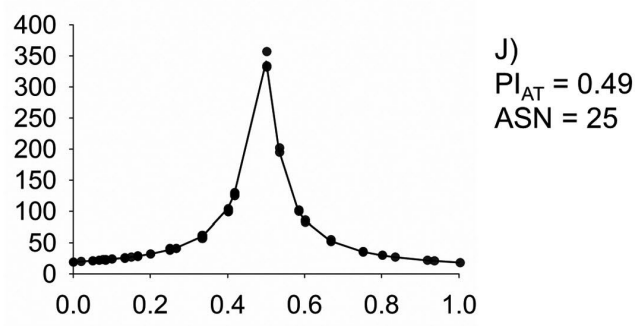

\section{Observed proportion infested}

Fig. 2. OC and ASN functions for binomial sequential sampling plans for action thresholds based on the proportion of infested sample units that correspond to a mean density of five stink bugs per 25 sweeps. The OC (panels A, C, E, G, and I) and ASN (panels B, D, F, H, and J) functions were plotted against the observed proportion infested obtained from resampling software. Panels $A$ and $B$ correspond to tally threshold of $1 ; C$ and $D$ correspond to tally threshold of 2; E and F correspond to tally threshold of $3 ; \mathrm{G}$ and $\mathrm{H}$ correspond to tally threshold of $4 ; \mathrm{I}$ and $\mathrm{J}$ correspond to tally threshold of 5 . Proportion infested action thresholds $\left(\mathrm{PI}_{\mathrm{AT}}\right)$ and actual $\alpha$ and $\beta$ error values are shown, based on preset values of $\alpha=\beta=0.10$ (see Table 3). 
proportion infested action threshold were less than 0.5 , suggesting the sampling plans were conservative, that is, treating at the proportion infested action threshold was more likely to occur. For the tally threshold of 3 stink bugs per 25 sweeps, the sampling plan was slightly liberal $(O C=0.51)$, that is, not treating at the proportion infested action threshold was more likely to occur. For the mean density threshold of 10 stink bugs per 25 sweeps, the OC for tally thresholds of 3,4 , and 5 stink bugs per 25 sweeps were $0.39,0.32$, and 0.36 respectively (Fig. 3A, C, and E). Because the OC values at the proportion infested action threshold were less than 0.5 , these sampling plans can be considered conservative.

Resampling analysis resulted in eight summary outputs that were used to develop the treatment decision probability matrix to determine the best possible combination of tally threshold and proportion infested action threshold (Table 3). All simulations had high probabilities (i.e., 0.994-0.999) of correct decisions $(A+D)$ and low probabilities (i.e., $0-0.005$ ) of incorrect decisions $(B+C$ ) (Table 3 ). The ASN required to reach a decision ranged from 15 to 25 and 12 to 13 sample units for the different combinations of tally thresholds and proportion infested action thresholds that corresponded to the mean densities of 5 and 10 stink bugs per 25 sweeps, respectively (Table 3). The maximum ASN required to reach a decision is near or at the proportion infested action threshold. The maximum ASN ranged from 67 to 357 (Fig. 2B, D, F, H, and J) and 49 to 88 (Fig. 3B, D, and F) sample units for the different combinations of tally thresholds and proportion infested action thresholds that corresponded to a mean density of 5 and 10 stink bugs per 25 sweeps, respectively.

Based on a pre-established criteria to select the optimum combinations of tally thresholds and proportion infested action thresholds (i.e., correct treat + not treat $>$ incorrect treat + not treat decisions; and incorrect treat $>$ incorrect not treat decisions; balance between actual $\alpha$ and $\beta$ values, and ASN), a tally threshold of 3 stink bugs per 25 sweeps was selected as the optimal tally threshold to be used for field implementation of the binomial sequential sampling plans that represented the action thresholds of 5 and 10 stink bugs per 25 sweeps. The use of one tally threshold for all field situations facilitates the development and execution of binomial sampling plans for herbivorous stink bugs. This tally threshold represents the best suitable balance 


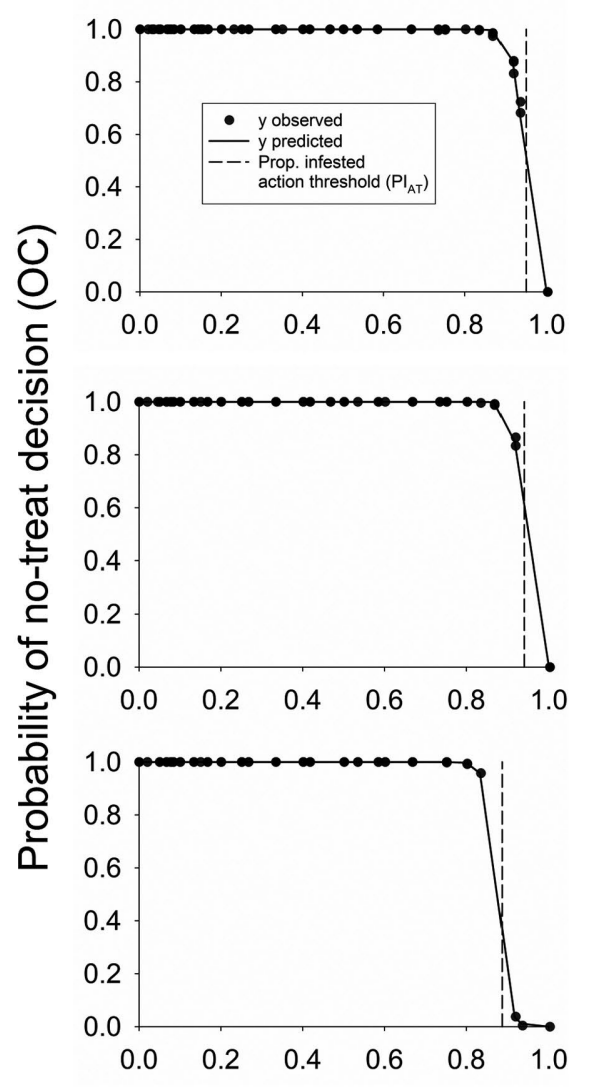

$$
\begin{aligned}
& \text { A) } \\
& \mathrm{Pl}_{\text {AT }}=0.95 \\
& \alpha=0.07, \quad \beta=0.07
\end{aligned}
$$

C)

$\mathrm{PI}_{\mathrm{AT}}=0.94$

$\alpha=0.08, \beta=0.03$

$\mathrm{E})$
$\mathrm{Pl}_{\mathrm{AT}}=0.88$
$\alpha=0.14, \beta=0.05$

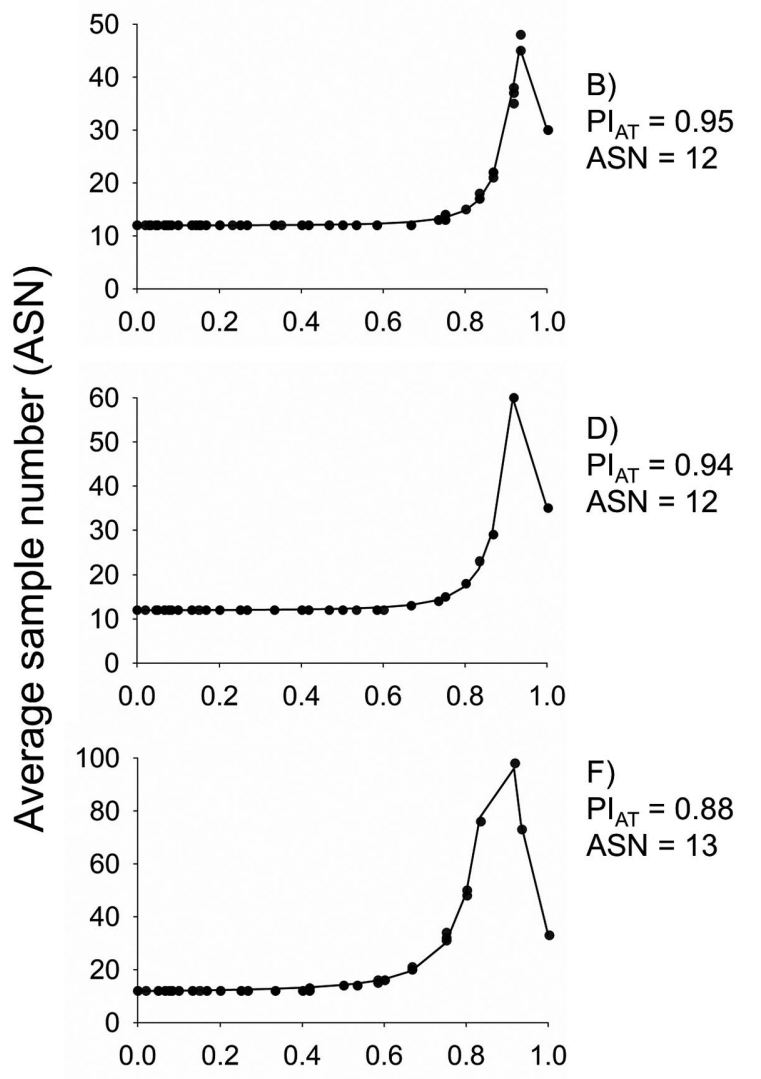

\section{Observed proportion infested}

Fig. 3. OC and ASN functions for binomial sequential sampling plans for action thresholds based on the proportion of infested sample units that correspond to a mean density of 10 stink bugs per 25 sweeps. The OC (panels $A, C$, and E) and ASN (panels $B, D$, and $F$ ) functions were plotted against the observed proportion infested obtained from resampling software. Panels $A$ and $B$ correspond to tally threshold of $3 ; C$ and $D$ correspond to tally threshold of $4 ; E$ and $F$ correspond to tally threshold of 5. Proportion infested action thresholds $\left(\mathrm{PI}_{\mathrm{AT}}\right)$ and actual $\alpha$ and $\beta$ error values are shown, based on preset values of $\alpha=\beta=0.10$ (see Table 3).

among the highest probability of correct (i.e., $A+D \geq 99 \%$ ) and lowest probability of incorrect (i.e., $B+C \leq 1 \%$ ) decisions, while minimizing actual $\alpha$ (i.e., for proportion infested action threshold of 0.75 and $0.95, \alpha=0.07$ ) and $\beta$ (i.e., for proportion infested action threshold of 0.75 and $0.95, \beta=0.09$ and 0.07 , respectively) error rates and ASN (i.e., for proportion infested action threshold of 0.75 and $0.95, A S N=18$ and 12 , respectively) compared to the other tally thresholds examined. 
Table 3. Decision matrix summary for the probability of correct and incorrect decisions, in relation to tally thresholds and action thresholds for a binomial sequential sampling plan for herbivorous stink bugs in the Midwest region of the United States.

\begin{tabular}{|c|c|c|c|c|c|c|c|c|c|c|}
\hline \multirow[b]{2}{*}{$\mathrm{AT}^{a}$} & \multirow[b]{2}{*}{$\mathrm{PI}_{A T^{b}}^{b}$} & \multirow[b]{2}{*}{$\alpha^{c}$} & \multirow[b]{2}{*}{$\beta^{c}$} & \multicolumn{3}{|c|}{ Correct decisions } & \multicolumn{4}{|c|}{ Incorrect decisions } \\
\hline & & & & $A^{d}$ & $D^{e}$ & $A+D^{f}$ & $B^{g}$ & $C^{h}$ & $B+C^{i}$ & ASN \\
\hline \multicolumn{11}{|c|}{ Tally threshold = 1} \\
\hline 5 & 0.95 & 0.083 & 0.078 & 0.048 & 0.948 & 0.996 & 0.000 & 0.003 & 0.003 & 14.55 \\
\hline \multicolumn{11}{|c|}{ Tally threshold $=2$} \\
\hline 5 & 0.86 & 0.098 & 0.097 & 0.036 & 0.960 & 0.997 & 0.001 & 0.001 & 0.002 & 16.47 \\
\hline \multicolumn{11}{|c|}{ Tally threshold $=3$} \\
\hline 5 & 0.75 & 0.077 & 0.095 & 0.029 & 0.965 & 0.994 & 0.004 & 0.000 & 0.005 & 18.47 \\
\hline 10 & 0.95 & 0.077 & 0.075 & 0.005 & 0.993 & 0.998 & 0.000 & 0.001 & 0.001 & 12.40 \\
\hline \multicolumn{11}{|c|}{ Tally threshold $=4$} \\
\hline 5 & 0.62 & 0.096 & 0.082 & 0.028 & 0.971 & 0.999 & 0.000 & 0.000 & 0.000 & 23.87 \\
\hline 10 & 0.94 & 0.083 & 0.032 & 0.004 & 0.995 & 0.999 & 0.000 & 0.000 & 0.000 & 12.34 \\
\hline \multicolumn{11}{|c|}{ Tally threshold $=5$} \\
\hline 5 & 0.49 & 0.093 & 0.105 & 0.028 & 0.970 & 0.998 & 0.001 & 0.000 & 0.001 & 24.52 \\
\hline 10 & 0.88 & 0.144 & 0.057 & 0.004 & 0.995 & 0.999 & 0.000 & 0.000 & 0.000 & 12.59 \\
\hline
\end{tabular}

Results are based on the observed and average proportion infested outcomes, and OC results from the resampling validations using independent data sets from 11 states, 2016-2018.

${ }^{a}$ Mean stink bug density per 25 sweeps that are the current action thresholds (AT) for stink bugs (i.e., soybean grown for seed $=5$ stink bugs per 25 sweeps; soybean grown for grain = 10 stink bugs per 25 sweeps).

${ }^{b}$ Proportion infested action threshold $\left(\mathrm{PI}_{\mathrm{AT}}\right)$, based on the proportion of infested sample units and mean relationship curves (Fig. 1).

${ }^{c}$ Type I error $(\alpha)$ is defined as the probability of making a treatment decision when proportion infested (PI) is below the AT. Type II error ( $\beta$ ) is defined as the probability of making a no-treat decision when $\mathrm{PI}$ is above the AT. Actual error values were estimated from the fitted curves in Figs. 2 and 3.

${ }^{d} A$, probability of making a correct treat decision.

${ }^{e} D$, probability of making a correct no-treat decision.

${ }^{f} A+D$, total probability of making a correct treat or no-treat decision.

${ }^{g} B$, probability of making an incorrect no-treat decision.

${ }^{h} \mathrm{C}$, probability of making an incorrect treat decision.

${ }^{\prime} B+C$, total probability of making an incorrect treat or no-treat decision.

Based on the above results, graphs with decision stop-lines for the tally threshold of 3 stink bugs per 25 sweeps and proportion infested action threshold of 0.75 (i.e., corresponding to an action threshold of 5 stink bugs per 25 sweeps) and 0.95 (i.e., corresponding to an action threshold of 10 stink bugs per 25 sweeps) were developed (Fig. 4A and B). When the proportion infested action threshold is 0.75 (i.e., $75 \%$ of 
A)

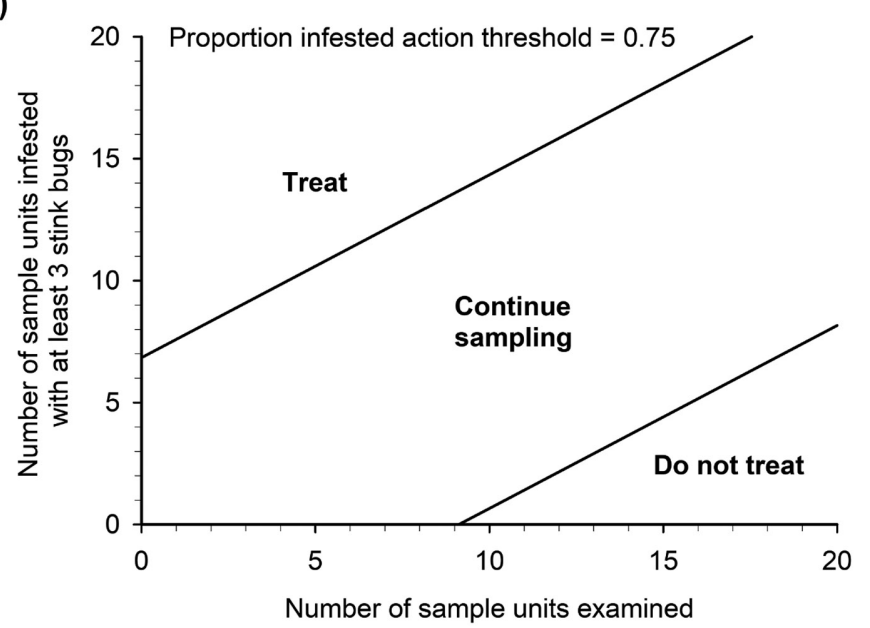

B)

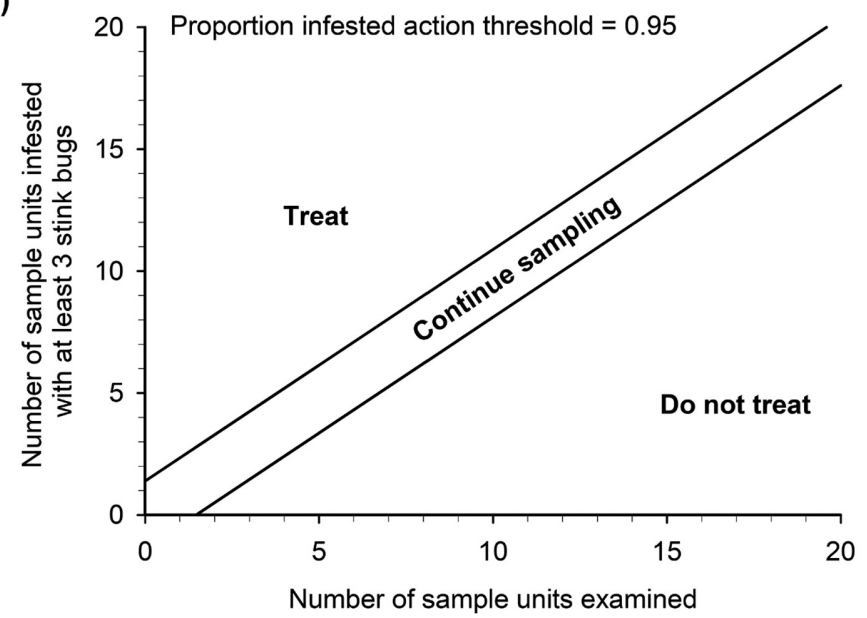

Fig. 4. Decision stop-lines for the binomial sequential sampling plans for herbivorous stink bugs in the Midwest region of the United States, where sample unit size $=25$ sweeps, $\alpha=\beta=0.10$, and tally threshold $=3$ (three or more stink bugs per sample unit to be considered infested). Panel A represents the proportion infested action threshold of 0.75 , which corresponds to a mean density action threshold of 5 stink bugs per 25 sweeps (upper line is $y=6.84+0.75 x$ and lower line is $y=-6.84$ $+0.75 x$ ). Panel $B$ represents the proportion infested action threshold of 0.95 , which corresponds to a mean density action threshold of 10 stink bugs per 25 sweeps (upper line is $y=1.39+0.95 x$ and lower line is $y=-1.39+0.95 x$ ). For implementation, we recommend a minimum of four sample units to make a decision. If a decision cannot be made after collecting 20 sample units, return to the field and sample again in 10-14 $\mathrm{d}$.

infested sample units), a minimum of nine sample units must be sampled to make a decision (Fig. 4A). When the proportion infested action threshold is 0.95 (i.e., $95 \%$ of infested sample units), a minimum of two sample units must be sampled to make a decision (Fig. 4B). 


\section{Discussion}

In this study, we developed and validated eight binomial sequential sampling plans based on five tally thresholds and two proportion infested action thresholds, using RVSP software based on Wald's sequential probability ratio test (Naranjo and Hutchison 1997) for herbivorous stink bugs in the Midwest region. The goal of this study was to identify the sampling plan combination that provided the most efficient decision-making outcome. Unlike enumerative sequential sampling plans, which are typically evaluated based on the precision level (Southwood 1978), binomial sequential sampling plans are evaluated based on Monte Carlo simulations (e.g., theoretical distribution) or by bootstrap simulations, examining the OC and ASN functions (Jones 1994, Naranjo and Hutchison 1997). The binomial sequential sampling plans in this study were evaluated using bootstrap simulations. This approach is usually more robust and more predictive than the Monte Carlo method (Fowler and Lynch 1987, Hutchison et al. 1988, Nyrop and Binns 1990), because actual field data are used to develop OC functions (Hutchison 1994, Naranjo and Hutchison 1997). The OC obtained from the resampling software was used with a decision probability matrix to select the optimal tally threshold and proportion infested action threshold (Burkness et al. 1999, Hodgson et al. 2004, Galvan et al. 2007).

All sampling plans delivered highly accurate classifications (i.e., the probability of making a correct treat or no-treat decision was always $>$ 99\%). For tally thresholds $\leq 3$ stink bugs per 25 sweeps, and action thresholds corresponding to a mean density of five stink bugs per 25 sweeps, the ASN was $\leq 18$ sample units. As the tally threshold increased (i.e., 4 and 5 stink bugs per 25 sweeps), the ASN increased by approximately $28 \%$. For tally thresholds of 3,4 , and 5 stink bugs per 25 sweeps and action thresholds corresponding to a mean density of 10 stink bugs per 25 sweeps, the ASN was near the minimum sample size of 12 sample units. A tally threshold of 3 stink bugs per 25 sweeps was selected as the optimal tally threshold to be used in the field, because this tally threshold presented the proper balance among OC, ASN, actual $\alpha$ and $\beta$, and high probability of correct decisions compared to other proposed tally thresholds. Although all sampling plans delivered highly accurate decisions, a tally threshold of 3 
stink bugs also provided the smallest actual $\alpha$ and $\beta$ error values over all the sampling plans. The $\alpha$ and $\beta$ error values are considered variables of the data and the resampling analysis (Naranjo and Hutchison 1997, Subramanyam et al. 1997, Paula-Moraes et al. 2011). The actual $\alpha$ and $\beta$ values were lower than the values originally input in RVSP (0.10) and represent a reduced probability of committing type I (implementing control measures when they are not necessary) and type II (not implementing control measures when they are necessary) errors. This is essential in today's soybean production where profit margins are narrow and making such errors would result in either unnecessary insecticide applications, which increase financial costs and environmental contamination, or missing necessary insecticide applications, which could result in significant yield loses that reduce financial gains. Of these, the latter error is potentially more serious for producers, and any sampling method with a high type II error rate will be unacceptable.

Stink bugs have aggregated spatial patterns in multiple crops (Espino et al. 2008, Reay-Jones et al. 2009, Babu and Reisig 2018, Fernandes et al. 2019, Pezzini et al. 2019a). With highly aggregated species, generally higher sample sizes are needed with enumerative sequential sampling plans designed to estimate insect density in the field (Jones 1994, Reay-Jones et al. 2009). Because binomial sequential sampling plans only classify the pest as either present or absent based on a tally threshold rather than a full count, this approach can greatly reduce sampling costs for highly aggregated pests (McGraw and Koppenhofer 2009). Overall, the ASN of our proposed sampling plans with a tally threshold equal to 3 stink bugs per 25 sweeps was 18 and 12 sample units for proportion infested action threshold of 0.75 and 0.95 , respectively, which are reasonable numbers for use in field-based decision making. Recommended sample sizes for stink bug sampling in soybean vary across the United States, ranging from two to 12 sample units with variable sample unit sizes (see Table 1 in Pezzini et al. [2019a]). Based on the ASN estimates for our proposed binomial sequential sampling plans, a soybean field could be sampled in approximately 42 and 28 min for ASN of 18 and 12 sample units, respectively. These time estimates were based on our recorded times of 1.22 min for walking between sample units and collecting a sample unit (unpublished data), and an additional 1.12 min for counting 
the stink bugs in a sample unit in the field, i.e., $50 \%$ of the time required to count stink bugs in two sets of 25 sweeps in cotton (ReayJones et al. 2009). A reasonable next step in this effort is implementing this approach across the region and determining whether these time estimates are representative.

Pezzini et al. (2019a) proposed an enumerative sequential sampling plan, with a desired precision of 0.25 , for herbivorous stink bugs in the Midwest region and found that an ASN of 40-42 sample units were needed. Our findings represent a significant reduction in sample size requirements when compared to an enumerative sequential sampling plan while retaining high levels of accuracy, efficiency, and improved practicality. Similarly, Hodgson et al. (2004) found that a binomial sequential sampling plan developed for the soybean aphid, Aphis glycines Matsumura (Hemiptera: Aphididae), improved efficiency in IPM decision making with an ASN of 11 plants compared to an ASN of 38 plants for a desired precision level of 0.25 for an enumerative sequential sampling plan.

As with most binomial sequential sampling plans, the greatest ASN for decision making occur near the action thresholds (Jones 1994, Naranjo and Hutchison 1997, Paula-Moraes et al. 2011). In a binomial sequential sampling plan, the density of the insect population impacts the number of sample units collected (Paula- Moraes et al. 2011). When stink bug densities are low or high, the binomial sequential sampling plans proposed here will provide the greatest savings in sampling since a no-treat or treat decision will be reached quickly.

For binomial sequential sampling, the point where the lower stopline intercepts the $x$-axis can indicate the minimum number of sample units required to reach a decision to treat or not treat (Subramanyam et al. 1997, Burkness and Hutchison 2009); however, in practice, we recommend that at least four sample units be collected prior to making a decision (Espino et al. 2008, Reay-Jones et al. 2009). Furthermore, because this is a sequential sampling plan, the proportion of infested sample units can potentially indicate that it is necessary to 'continue sampling' indefinitely. One of the main advantages of a binomial sequential sampling plan is that it is practical (i.e., a decision could be made after each sample unit), minimizing the effort and 
time of the scout. Therefore, based on our analysis, we recommend a limit of 20 sample units to arrive at a decision. If 20 sample units have been collected, and no decision has been reached, the field should be resampled in 10-14 d.

Binomial sequential sampling plans have been developed for beatcloth sampling for stink bugs in soybean in Brazil (Souza et al. 2014, Fernandes et al. 2019). To our knowledge, this is the first proposed binomial sequential sampling plan for herbivorous stink bugs in soybean in the Midwest region. In Brazil and the United States, which are worldwide leaders in soybean production, IPM can be challenging, where the grower is confronted with the need for a quicker and easier pest sampling methodology that may reduce prophylactic insecticide applications that occur when scouting is too tedious and time intensive (Bueno et al. 2020). Results of this research found that the binomial sequential sampling plans can improve efficiency by reducing the number of sample units required to reach a management decision for the region. In addition, the sampling plan parameters used in this study can easily be adjusted to accommodate other action thresholds and allowable error rates suitable for a specific geographic region. However, continued efforts should be made to evaluate the costs and benefits of the proposed binomial sequential sampling plans across the Midwest region (e.g., Hodgson et al. 2007).

\section{$\diamond \diamond \diamond$}

Supplementary Data Supplementary Tables S1 - S3 follow the References.

Acknowledgments The authors thank J. Menger, K. Rich, P. Anderson, T. Eicholz, N. Bueno, L. Wallace, P. Mittapelly, N. Luhr, T. DeVries, P. Beauzay, A. Knudson, T. Nelson, L. Bledsoe, J. Gunn, T. Leslie, P. Rozebom, S. Losey, and A. Decker for collecting and processing samples, and B. Aukema and M. Asplen for reviewing an earlier version of this manuscript. We also thank the North Central Soybean Research Program who provided funding for the research. 


\section{References Cited}

Araújo, T. A. D., D. T. Pezzini, R. S. Ramos, M. C. Picanço, C. S. Bastos, T. E. Hunt, and W. D. Hutchison. 2020. Development and validation of sampling plans for Frankliniella schultzei on tomato. Crop Prot. 134: 105163.

Babu, A., and D. D. Reisig. 2018. Developing a sampling plan for brown stink bug (Hemiptera: Pentatomidae) in field corn. J. Econ. Entomol. 111: 1915-1926.

Binns, M. R. 1994. Sequential sampling for classifying pest status, pp. 137- 174. In L. Pedigo and G. Buntin (eds.), Handbook of sampling methods for arthropods in agriculture. CRC Press, Boca Raton, FL.

Binns, M. R., and J. P. Nyrop. 1992. Sampling insect populations for the purpose of IPM decision making. Annu. Rev. Entomol. 37: 427-453.

Binns, M. R., J. P. Nyrop, and W. van der Werf. 2000. Sampling and monitoring in crop protection. CABI Publishing, Oxon, United Kingdom.

Bueno, A. F., A. R. Panizzi, T. E. Hunt, P. M. D. Dourado, R. M. P. Pitta, and J. G. Gonçalves. 2020. Challenges for adoption of integrated pest management (IPM): the soybean example. Neotrop. Entomol. 50: 5-20. doi:10.1007/ s13744-020-00792-9.

Burkness, E. C., and W. D. Hutchison. 1997. Development and validation of a binomial sequential sampling plan for striped cucumber beetle (Coleoptera: Chrysomelidae) in cucurbits. J. Econ. Entomol. 90: 1590-1594.

Burkness, E. C., and W. D. Hutchison. 2009. Implementing reduced-risk integrated pest management in fresh-market cabbage: influence of sampling parameters, and validation of binomial sequential sampling plans for the cabbage looper (Lepidoptera: Noctuidae). J. Econ. Entomol. 102: 1874-1883.

Burkness, E. C., R. C. Venette, P. K. O'Rourke, and W. D. Hutchison. 1999. Binomial sequential sampling for management of aster leafhopper (Homoptera: Cicadellidae) and aster yellows phytoplasma in carrot: impact of tally threshold on the accuracy of treatment decisions. Environ. Entomol. 28: 851-857.

Calvin, D. D., M. C. Knapp, K. Xingquan, F. L. Poston, and S. M. Welch. 1986. Using a decision model to optimize European corn borer (Lepidoptera: Pyralidae) egg-mass sampling. Environ. Entomol. 15: 1212-1219.

DeCoursey, R. M., and C. O. Esselbaugh. 1962. Descriptions of the nymphal stages of some North American Pentatomidae (Hemiptera: Heteroptera). Ann. Entomol. Soc. Am. 55: 323-342.

Espino, L., M. O. Way, and L. T. Wilson. 2008. Determination of Oebalus pugnax (Hemiptera: Pentatomidae) spatial pattern in rice and development of visual sampling methods and population sampling plans. J. Econ. Entomol. 101: 216-225.

Evans, E. W. 1985. A key to nymphs of four species of the genus Podisus (Hemiptera: Pentatomidae) of northeastern North America. Proc. Entomol. Soc. Wash. 87: 94-97.

Fehr, W. R., and C. E. Caviness. 1977. Stages of soybean development. lowa State University Cooperative Extension Service Special Rep. 80. Iowa State University, Ames, IA. 
Fernandes, M. G., E. N. Costa, L. H. Cavada, T. A. Mota, and P. R. B. da Fonseca. 2019. Spatial distribution and sampling plan of the phytophagous stink bug complex in different soybean production systems. J. Appl. Entomol. 143: 236-249.

Fowler, G. W., and A. M. Lynch. 1987. Sampling plans in insect pest management based on Wald's sequential probability ratio test. Environ. Entomol. 16: 345-354.

Galvan, T. L., E. C. Burkness, and W. D. Hutchison. 2007. Enumerative and binomial sequential sampling plans for the multicolored Asian lady beetle (Coleoptera: Coccinellidae) in wine grapes. J. Econ. Entomol. 100: 1000-1010.

Hodgson, E. W., E. C. Burkness, W. D. Hutchison, and D. W. Ragsdale. 2004. Enumerative and binomial sequential sampling plans for soybean aphid (Homoptera: Aphididae) in soybean. J. Econ. Entomol. 97: 2127-2136.

Hodgson, E. W., B. P. McCornack, K. A. Koch, D. W. Ragsdale, K. D. Johnson, M. E. O'Neal, E. M. Cullen, H. J. Kraiss, C. D. DiFonzo, and L. M. Behnken. 2007. Field validation of speed scouting for soybean aphid. Crop Manag. 6: 1-8.

Hoebeke, E. R., and E. M. Carter. 2003. Halyomorpha halys (Stal) (Heteroptera: Pentatomidae) a polyphagous plant pest from Asia newly detected in North America. Proc. Entomol. Soc. Wash. 105: 225-237.

Hutchison, W. D. 1994. Sequential sampling to determine population density, pp. 207-244. In L. Pedigo and G. Buntin (eds.), Handbook of sampling methods for arthropods in agriculture. CRC, Boca Raton, FL.

Hutchison, W. D., D. B. Hogg, A. M. Poswal, R. C. Berberet, and G. W. Cuperus. 1988. Implications of the stochastic nature of Kuno's and Green's fixedprecision stop lines: sampling plans for the pea aphid (Homoptera: Aphididae) in alfalfa as an example. J. Econ. Entomol. 81: 749-758.

Jones, V. P. 1994. Sequential estimation and classification procedures for binomial counts, pp. 175-205. In L. Pedigo and G. Buntin (eds.), Handbook of sampling methods for arthropods in agriculture. CRC, Boca Raton, FL.

Kistner, E. J. 2017. Climate change impacts on the potential distribution and abundance of the brown marmorated stink bug (Hemiptera: Pentatomidae) with special reference to North America and Europe. Environ. Entomol. 46: 1212-1224.

Koch, R. L. 2014. Detection of the brown marmorated stink bug (Hemiptera: Pentatomidae) in Minnesota. J. Entomol. Sci. 49: 313-317.

Koch, R. L., and T. Pahs. 2014. Species composition, abundance, and seasonal dynamics of stink bugs (Hemiptera: Pentatomidae) in Minnesota soybean fields. Environ. Entomol. 43: 883-888.

Koch, R. L., and W. A. Rich. 2015. Stink bug (Hemiptera: Heteroptera: Pentatomidae) feeding and phenology on early-maturing soybean in Minnesota. J. Econ. Entomol. 108: 2335-2343.

Koch, R. L., D. T. Pezzini, A. P. Michel, and T. E. Hunt. 2017. Identification, biology, impacts, and management of stink bugs (Hemiptera: Heteroptera: Pentatomidae) of soybean and corn in the midwestern United States. J. Integr. Pest Manag. 8: 1-14. 
Koch, R. L., A. Ambourn, and J. Burington. 2018. Detections of Bagrada hilaris (Hemiptera: Pentatomidae) in Minnesota. J. Entomol. Sci. 53: 278-280.

Kogan, M. 1976. Soybean disease and insect pest management, pp. 114-121. In R. M. Goodman (eds.), Expanding the use of soybeans. Proceedings of a Conference for Asia and Oceania, p. 261. University of Illinois at UrbanaChampaign, INTSOY. Ser. 10.

Kogan, M., and H. N. Pitre. 1980. General sampling methods for aboveground population of soybean arthropods, pp. 30-60. In M. Kogan and D. C. Herzog (eds.), Sampling methods in soybean entomology. Springer, New York, NY.

Leskey, T. C., G. C. Hamilton, A. L. Nielsen, D. F. Polk, C. Rodriguez-Saona, J. Christopher Bergh, D. Ames Herbert, T. P. Kuhar, D. Pfeiffer, G. P. Dively, et al. 2012. Pest status of the brown marmorated stink bug, Halyomorpha halys in the USA. Outlooks Pest Manag. 23: 218-226.

Lindenmayer, J. C., K. L. Giles, N. C. Elliott, A. E. Knutson, R. Bowling, M. J. Brewer, N. J. Seiter, B. McCornack, S. A. Brown, A. L. Catchot, et al. 2020. Development of binomial sequential sampling plans for sugarcane aphid (Hemiptera: Aphididae) in commercial grain sorghum. J. Econ. Entomol. 113: 1990-1998.

McGraw, B. A., and A. M. Koppenhöfer. 2009. Development of binomial sequential sampling plans for forecasting Listronotus maculicollis (Coleoptera: Curculionidae) larvae based on the relationship to adult counts and turfgrass damage. J. Econ. Entomol. 102: 1325-1335.

McPherson, J. E. 2018. Invasive stink bugs and related species (Pentatomoidea): biology, higher systematics, semiochemistry, and management. CRC Press, Boca Raton, FL.

McPherson, J. E., and R. M. McPherson. 2000. Stink bugs of economic importance in America North of Mexico. CRC Press LCC, Boca Raton, FL.

Moon, R. D., and L. T. Wilson. 2008. Sampling for detection, estimation and IPM decision making, pp. 75-89. In E. B. Radcliffe, W. D. Hutchison, and R. E. Cancelado (eds.), Integrated pest management: concepts, tactics, strategies, and case studies. Cambridge University Press, Cambridge, United Kingdom.

Naranjo, S. E., and W. D. Hutchison. 1997. Validation of arthropod sampling plans using a resampling approach: software and analysis. Am. Entomol. 43: 48-57.

Northeastern IPM Center (NIPMC). 2020. Where is BMSB? (http://www.stopbmsb. org/where-is-bmsb/state-by-state/) (accessed 7 October 2020).

Nyrop, J. P., and M. R. Binns. 1990. Quantitative methods for designing and analyzing sampling programs for use in pest management, pp. 67-132. In D. Pimentel (ed.), Handbook of pest management in agriculture. CRC, Boca Raton, FL.

Onsager, J. A. 1976. The rationale of sequential sampling, with emphasis on its use in pest management. U.S. Dep. Agric. Tech. Bull. 1526.

Pagano, M. C., and M. Miransari. 2016. The importance of soybean production worldwide, pp. 1-26. In Abiotic and biotic stresses in soybean production, vol. 1. Elsevier Inc., United Kingdom. 
Paiero, S. M., S. A. Marshall, J. E. McPherson, and M.-S. Ma. 2013. Stink bugs (Pentatomidae) and parent bugs (Acanthosomatidae) of Ontario and adjacent areas: a key to species and a review of the fauna. Can. J. Arthropod Identif. 24: $1-183$.

Panizzi, A. R. 2015. Growing problems with stink bugs (Hemiptera: Heteroptera: Pentatomidae): species invasive to the U. S. and potential Neotropical invaders. Am. Entomol. 61: 223-233.

Paula-Moraes, S., E. C. Burkness, T. E. Hunt, R. J. Wright, G. L. Hein, and W. D. Hutchison. 2011. Cost-effective binomial sequential sampling of western bean cutworm, Striacosta albicosta (Lepidoptera: Noctuidae), egg masses in corn. J. Econ. Entomol. 104: 1900-1908.

Pezzini, D. T., C. D. DiFonzo, D. L. Finke, T. E. Hunt, J. J. Knodel, C. H. Krupke, B. McCornack, A. P. Michel, R. D. Moon, C. R. Philips, et al. 2019a. Spatial patterns and sequential sampling plans for estimating densities of stink bugs (Hemiptera: Pentatomidae) in soybean in the North Central Region of the United States. J. Econ. Entomol. 112: 1732-1740.

Pezzini, D. T., C. D. DiFonzo, D. L. Finke, T. E. Hunt, J. J. Knodel, C. H. Krupke, B. McCornack, A. P. Michel, C. R. Philips, A. J. Varenhorst, et al. 2019b. Community composition, abundance, and phenology of stink bugs (Hemiptera: Pentatomidae) in soybean in the North Central Region of the United States. J. Econ. Entomol. 112: 1722-1731.

Reay-Jones, F. P., J. K. Greene, M. D. Toews, and R. B. Reeves. 2009. Sampling stink bugs (Hemiptera: Pentatomidae) for population estimation and pest management in southeastern cotton production. J. Econ. Entomol. 102: 2360-2370.

Rider, D. A. 2012. The Heteroptera (Hemiptera) of North Dakota I: Pentatomomorpha: Pentatomoidea. Great Lakes Entomol. 45: 312-380.

Sane, I., D. R. Alverson, and J. W. Chapin. 1999. Efficiency of conventional sampling methods for determining arthropod densities in close-row soybeans. J. Agric. Urban Entomol. 16: 65-84.

Southwood, T. R. E. 1978. Ecological methods with particular reference to the study of insect populations. Chapman \& Hall, London, United Kingdom.

Souza de, L. A., J. C. Barbosa, J. F. J. Grigolli, D. F. Fraga, L. C. Moraes, and A. C. Busoli. 2014. Sequential sampling of Euschistus heros (Heteroptera: Pentatomidae) in soybean. Sci. Agric. 71: 464-471.

Subramanyam, B., D. W. Hagstrum, R. L. Meagher, E. C. Burkness, W. D. Hutchison, and S. E. Naranjo. 1997. Development and evaluation of sequential sampling plans for Cryptolestes ferrugineus (Stephens) (Coleoptera: Cucujidae) infesting farm-stored wheat. J. Stored Prod. Res. 33: 321-329.

Tindall, K. V., and K. Fothergill. 2011. First records of Piezodorus guildinii in Missouri. Southwest. Entomol. 36: 203-205.

Tindall, K. V., K. Fothergill, and B. McCormack. 2012. Halyomorpha halys (Hemiptera: Pentatomidae): a first Kansas record. J. Kansas Entomol. Soc. 85: 169-169. 
Todd, J. W., and D. C. Herzog. 1980. Sampling phytophagous Pentatomidae on soybean, pp. 438-478. In M. Kogan and D. C. Herzog (eds.), Sampling methods in soybean entomology. Springer, New York.

U.S. Department of Agriculture-Economic Research Service (USDA-ERS). 2020. Soybean \& oil crops-oil crops sector at a glance. (https://www.ers.usda.gov/ topics/crops/soybeans-oil-crops/oil-crops-sector-at-a-glance/) (accessed 15 October 2020).

U.S. Department of Agriculture-National Agricultural Statistics Service (USDANASS). 2019. Agricultural chemical use survey: soybeans. (https://www.nass. usda.gov/Surveys/Guide_to_NASS_Surveys/Chemical_Use/2018_Peanuts_ Soybeans_Corn/ChemUseHighlights_Soybeans_2018.pdf) (accessed 10 October 2020).

Wald, A. 1947. Sequential analysis. Wiley, New York. 
Supplemental Table S1. Parameter estimates from a logistic dose-response function used to fit the relationship between the proportion of infested sample units as a function of the mean density of stink bugs per 25 sweeps

\begin{tabular}{|c|c|c|c|c|c|c|}
\hline \multirow[t]{2}{*}{$\mathrm{TT}^{a}$} & \multicolumn{3}{|c|}{ Parameter estimates $\pm \mathrm{SEM}^{b}$} & \multirow[t]{2}{*}{$\mathrm{R}^{2}$} & \multirow[t]{2}{*}{$F_{2,704}$} & \multirow[t]{2}{*}{$P$} \\
\hline & $\mathrm{a}$ & $\mathrm{b}$ & $\mathrm{c}$ & & & \\
\hline 1 & $1.12 \pm 0.02$ & $0.99 \pm 0.05$ & $-1.07 \pm 0.02$ & 0.93 & 5103.06 & $<0.001$ \\
\hline 2 & $1.06 \pm 0.02$ & $1.99 \pm 0.07$ & $-1.60 \pm 0.04$ & 0.94 & 5564.02 & $<0.001$ \\
\hline 3 & $1.05 \pm 0.03$ & $3.10 \pm 0.11$ & $-1.92 \pm 0.05$ & 0.93 & 4909.61 & $<0.001$ \\
\hline 4 & $1.11 \pm 0.03$ & $4.43 \pm 0.15$ & $-2.12 \pm 0.06$ & 0.94 & 5565.71 & $<0.001$ \\
\hline 5 & $1.08 \pm 0.03$ & $5.37 \pm 0.17$ & $-2.42 \pm 0.07$ & 0.93 & 5054.42 & $<0.001$ \\
\hline
\end{tabular}

${ }^{a}$ This relationship for the data sets at a given tally threshold (TT) was used to transform the mean density action thresholds to proportion infested action thresholds.

${ }^{b}$ Equation type is a logistic dose response of the form: $y=a /\left(1+(x / b)^{c}\right)$. 
Supplemental Table S2. Parameter estimates from a logistic-dose response formula used to fit the operating characteristic (OC) curves as a function of the observed proportion of infested sample units obtained from resampling software (RVSP), using field data for each tally threshold (TT) and proportion infested action threshold ( $\left.\mathrm{PI}_{\mathrm{AT}}\right)$ combination.

\begin{tabular}{cccccccc}
\hline \hline $\mathrm{PI}_{\mathrm{AT}}$ & $\mathrm{TT}$ & \multicolumn{3}{c}{ Parameter estimates $\pm \mathrm{SEM}^{a}$} & & $\mathrm{R}^{2}$ & $F_{2,704}$ \\
\hline & & $\mathrm{a}$ & $\mathrm{b}$ & $\mathrm{c}$ & & \\
$0.95^{b}$ & 1 & $0.99 \pm 0.00$ & $0.94 \pm 0.00$ & $77.11 \pm 0.72$ & 0.99 & 381832.70 & $<0.001$ \\
$0.86^{b}$ & 2 & $0.99 \pm 0.00$ & $0.85 \pm 0.00$ & $63.82 \pm 0.19$ & 0.99 & 3693079.00 & $<0.001$ \\
$0.75^{b}$ & 3 & $0.99 \pm 0.00$ & $0.75 \pm 0.00$ & $59.18 \pm 0.43$ & 0.99 & 2011823.00 & $<0.001$ \\
$0.95^{c}$ & 3 & $0.99 \pm 0.00$ & $0.94 \pm 0.00$ & $67.36 \pm 0.74$ & 0.99 & 226607.00 & $<0.001$ \\
$0.62^{b}$ & 4 & $1.00 \pm 0.00$ & $0.62 \pm 0.00$ & $58.20 \pm 0.14$ & 0.99 & 32948592.00 & $<0.001$ \\
$0.94^{c}$ & 4 & $0.99 \pm 0.00$ & $0.93 \pm 0.00$ & $91.17 \pm 3.17$ & 0.99 & 1507724.00 & $<0.001$ \\
$0.49^{b}$ & 5 & $0.99 \pm 0.00$ & $0.48 \pm 0.00$ & $35.99 \pm 0.38$ & 0.99 & 3685510.00 & $<0.001$ \\
$0.88^{c}$ & 5 & $0.99 \pm 0.00$ & $0.87 \pm 0.00$ & $67.26 \pm 0.13$ & 0.99 & $10948715.00<<0.001$ \\
\hline
\end{tabular}

${ }^{a}$ Equation type is a logistic dose response of the form: $y=a /\left(1+(x / b)^{c}\right)$.

${ }^{b}$ This $\mathrm{PI}_{\mathrm{AT}}$ corresponds to the action threshold of 5 stink bugs per 25 sweeps.

${ }^{c}$ This $\mathrm{PI}_{\mathrm{AT}}$ corresponds to the action threshold of 10 stink bugs per 25 sweeps. 
Supplemental Table S3. Parameter estimates from a Pearson VII formula used to fit the average sample number (ASN) curves as a function of the observed proportion of infested sample units obtained from resampling software (RVSP) using field data for each tally threshold (TT) and proportion infested action threshold ( $\left.\mathrm{PI}_{\mathrm{AT}}\right)$ combination

\begin{tabular}{|c|c|c|c|c|c|c|c|c|c|}
\hline \multirow[t]{2}{*}{$\mathrm{PI}_{\mathrm{AT}}$} & \multirow[t]{2}{*}{$\mathrm{TT}$} & \multicolumn{5}{|c|}{ Parameter estimates $\pm \mathrm{SEM}^{a}$} & \multirow[t]{2}{*}{$\mathrm{R}^{2}$} & \multirow[t]{2}{*}{$F_{4,702}$} & \multirow[t]{2}{*}{$P$} \\
\hline & & $\mathrm{a}$ & $\mathrm{b}$ & $\mathrm{c}$ & $\mathrm{d}$ & $\mathrm{e}$ & & & \\
\hline $0.95^{b}$ & 1 & $11.50 \pm 0.03$ & $55.91 \pm 0.38$ & $0.95 \pm 0.00$ & $0.08 \pm 0.00$ & $0.80 \pm 0.01$ & 0.99 & 48038.66 & $<0.001$ \\
\hline $0.86^{b}$ & 2 & $9.93 \pm 0.07$ & $164.84 \pm 0.49$ & $0.86 \pm 0.00$ & $0.09 \pm 0.00$ & $0.72 \pm 0.00$ & 0.99 & 80739.14 & $<0.001$ \\
\hline $0.75^{b}$ & 3 & $5.95 \pm 0.24$ & $258.74 \pm 0.63$ & $0.74 \pm 0.00$ & $0.09 \pm 0.00$ & $0.61 \pm 0.00$ & 0.99 & 71954.19 & $<0.001$ \\
\hline $0.95^{c}$ & 3 & $11.93 \pm 0.00$ & $37.26 \pm 0.24$ & $0.94 \pm 0.00$ & $0.09 \pm 0.00$ & $1.22 \pm 0.02$ & 0.99 & 37155.50 & $<0.001$ \\
\hline $0.62^{b}$ & 4 & $4.88 \pm 0.16$ & $411.61 \pm 2.62$ & $0.62 \pm 0.00$ & $0.09 \pm 0.00$ & $0.59 \pm 0.00$ & 0.99 & 295217.50 & $<0.001$ \\
\hline $0.94^{c}$ & 4 & $11.91 \pm 0.00$ & $57.66 \pm 0.23$ & $0.93 \pm 0.00$ & $0.09 \pm 0.00$ & $1.20 \pm 0.01$ & 0.99 & 131581.80 & $<0.001$ \\
\hline $0.49^{b}$ & 5 & $2.72 \pm 0.31$ & $357.05 \pm 0.95$ & $0.49 \pm 0.00$ & $0.09 \pm 0.00$ & $0.55 \pm 0.00$ & 0.99 & 163170.50 & $<0.001$ \\
\hline $0.88^{c}$ & 5 & $11.32 \pm 0.03$ & $116.60 \pm 1.30$ & $0.88 \pm 0.00$ & $0.11 \pm 0.00$ & $0.93 \pm 0.01$ & 0.99 & 53160.65 & $<0.001$ \\
\hline
\end{tabular}

${ }^{a}$ Equation type is Pearson VII of the form: $y=a+b /\left(1+4 \times((x-c) / d)^{2}\left(2^{(1 / e)^{-1}}\right)\right)^{e}$.

${ }^{b}$ This $\mathrm{PI}_{\mathrm{AT}}$ corresponds to the action threshold of 5 stink bugs per 25 sweeps.

${ }^{c}$ This $\mathrm{PI}_{\mathrm{AT}}$ corresponds to the action threshold of 10 stink bugs per 25 sweeps. 